\title{
Community and Help Seeking
}

\author{
Griselda Chapa* \\ Adjunct Faculty Department of Continuing Studies Division of Health and Wellness Tulane University, LA, USA
}

While I was writing my master's thesis on family planning and Hispanic immigrant women, I was recruited to run a non-profit in Chicago - The Hispanic Health Alliance (HHA). I had met some of their board members when I started researching potential thesis topics. The resume I had given them indicated Spanish was my first language. I had worked as a medical translator while I was in college. My degree was in health education. Part of my graduate scholarship required I teach human sexuality to undergraduate students. While I was in school, I translated information on cervical cancer for the local chapter of the National Cancer Institute. I also did radio and television shows about cervical cancer and family planning on local Spanish networks. If nothing else, the board members I had worked with knew I was motivated, educated and not easily embarrassed.

It was the 80's and AIDS had had hit Chicago very hard. My very humble office had mismatched furniture, didn't have air conditioning and was next to the elevated train station. I had a very small staff. Five were college interns and one was a community worker. The interns were doing a video on AIDS for local high schools. The community worker was a Vietnam veteran and a former heroin user. He was my community contact for a National Institute of Drug Abuse (NIDA) study focusing on Mexican Vietnam veterans and heroin use.

We had city funding targeting recent Spanish-speaking immigrants and health education including AIDS prevention, and Cook County funding to prevent adolescent pregnancy, which also had a safe sex component. We were part of a federal initiative called Condoms and Curls where we distributed condoms to beauty parlors. We also had the largest in-kind grant for condoms Trojan had given any organization. Having staff and funding may sound like enough to be successful, but community interventions, I learned, were a lot harder in real life than on paper.

My board told me to get to know other community non-profits, especially those who were my neighbors. Across the street from me there was a methadone program and across the hall from me was the Hispanic AIDS Network. However, community also meant other organizations serving Hispanics as well as those addressing AIDS issues. Since I was away from the office so much, I moved into the neighborhood Neighbors would see me at the local food joints, in the bodegas, and I would make it a point to tell them a few things we were doing and invite them to the office if they had anything they wanted us to address.

One day, very early on in my tenure, two Puerto Rican men came to my office --an older gentleman and his translator. Whenever someone came to see me, I moved us from my desk to a small table. I wanted my visitors to feel we were having a conversation. I asked them if they wanted coffee or water. The translator told me, in accented English, they knew I was busy so they declined the offer even after I insisted. In the only medical anthropology class I had taken, the professor had pointed out the importance of food in forming relationships. I remembered him saying the word companion came from combining the Latin words for com or with and panis for bread.

I smiled at the non-English speaker to reiterate I wasn't too busy to talk. This may seem obvious - we were going to meet. But the office shook every time a train passed and that was every fifteen minutes. Because of this people had to say thinks louder than normal and my staff was in a small space. Privacy was such a big issue sometimes I would ask the visitor if they had time to run an errand with me, then my car became my office. I couldn't take live notes, still, this was the best I could do for privacy. I also never assumed, when two people came to see me, the nature of their relationship. The translator in my story could have been the other man's neighbor, partner, or brother-in-law. I did know the translator was there for more than just translation. He was there for morale support, he was there in case I didn't understand the nuances of the older man's concerns.

The translator said the older gentleman was troubled about the empty lots with overgrown weeds. I must have looked very confused. Maybe they thought I just didn't understand the words. So I smiled again, this time sweeping both their faces. I switched to Spanish and said, "gracias, pero no entiendo" - Thank you but I don't understand. My office didn't have any environmental health or sanitation programs. The only problem I could have imagined were rats but I said nothing. I waited for them to give me their concerns. They started by saying the neighborhood children played in these overgrown urban "selvas" or jungles. They paused to give me a chance to react but I was clueless. Still, I felt we had made a connection so I pulled out a notebook. It was time for me to document their concerns - to show them I wouldn't forget the details.

They explained that the children keep finding "preservativos" in the empty lots.

A doctor on the board was a lead reduction activist. Could they mean chemicals? I was still lost and this must have been apparent. The older man blushed while the younger one, also embarrassed, explained that "preservatives" were used during sex. I had taught human sexuality four semesters and I trained at the University of Illinois' medical school. The younger man looked around my office and pointed to a box of Trojan condoms on the floor. I had never heard that word for condoms in Spanish.

The empty lots, according to my guests and informers, were littered with used condoms. On top of that there was a problem with "agujas". "Aguja", literally translated, means needles. Could they be concerned about tetanus? I knew the schools in the area were confused about vaccination protocols for HIV+ children. They couldn't have live vaccines but tetanus wasn't a live vaccine. I looked up from my notepad

*Corresponding author: Griselda Chapa, Adjunct Faculty Department of Continuing Studies Division of Health and Wellness Tulane University, LA, USA, Tel: 504-224-0705; E-mail: gchapa@tulane.edu

Received September 30, 2015; Accepted October 15, 2015; Published October 23, 2015

Citation: Chapa G (2015) Community and Help Seeking. J AIDS Clin Res 6: 512 doi:10.4172/2155-6113.1000512

Copyright: (c) 2015 Chapa G. This is an open-access article distributed under the terms of the Creative Commons Attribution License, which permits unrestricted use, distribution, and reproduction in any medium, provided the original author and source are credited. 
hoping they would see I wanted to help. I told them I would do what I could about the lots. I was thinking how much more dangerous rats would be than needles but I did not want to further scare them. I couldn't stop thinking about rats because a rat bit me in Chicago when I was four - this was what I knew. But I couldn't specify rats because if I did they might not tell me their real concern. I remembered community research professors telling us not to ask questions that had our concerns because a community intervention is for the community. First my guests said the more obvious, which did include tetanus and the they finally said "SIDA". They were afraid of AIDS. They were worried about HIV infected needles. My NIDA grant involved needle exchange but, in retrospect, it never occurred to me what people did with used needles. This type of community information, from people who can fill in information for both service providers and researchers, is a vital for creating relevant interventions.

As I brought in more grants, local funders asked me to review proposals and when I did, my comments, I felt, were not always taken seriously. I was in grant meetings in support of community facing programs - not for the sake of pure research. I was the community advocate. It was a great privilege to learn from real people but if I, sometimes, felt voiceless, how did they feel? 